\title{
The Effect of Promotion on Purchasing Decisions at PT. Auto 2000 Bintaro
}

\author{
Mahnun Mas'adi \\ Pamulang University \\ E-mail: dosen01017@unpam.ac.id
}

\begin{abstract}
This study aims to determine the effect of promotion on purchasing decisions at PT. AUTO 2000 Bintaro. The method used is explanatory research with a sample of 85 respondents. The analysis technique uses statistical analysis with regression testing, correlation, determination, and hypothesis testing. The results of this research variable Promotion obtained an average score of 3.42 with good criteria. The purchasing decision variable obtained an average score of 3.83 with good criteria. The promotion has a significant effect on purchasing decisions with the regression equation $\mathrm{Y}=8.949+0.862 \mathrm{X}$, and a correlation value of 0.772 or strong with a determination of $59.5 \%$. Hypothesis testing obtained a significance of 0.000 $<0.05$.
\end{abstract}

Keywords: Promotion; purchase decision; costumer

\section{INTRODUCTION}

Along with the increasing purchasing power of society, the demand for a product or service both in quality and quantity will also increase, this encourages producers to compete to offer various kinds of products to consumers. (Abishovna, 2014; Adams et al., 2019; Ellram \& Ueltschy Murfield, 2019). In terms of the increasing demand for vehicles, the middle class currently wants a vehicle that can carry more passengers at an affordable price (Harriss, 1995; Murtiasih et al., 2013; Nurcahyo \& Wibowo, 2015).

Competition in the car industry is getting tighter, Toyota, Honda, Mazda, Suzuki, and others offer optimal service, competitive prices, quality products, easy payment is affordable either by cash or credit, this competition often makes companies have to review the implementation of promotions and implement sales strategies. to be right on target (Cusumano \& Nobeoka, 1992; Proff, 2000; Shander et al., 2019). Obstacles that are often faced by companies are not achieving sales targets due to minimal allocation of promotional costs, not comparable between the number of marketing personnel and sales results, the performance of salespeople who are not able to take advantage of the market to prices that are often still above the prices of competing industries (Chiu et al., 2011; Passey \& MacGill, 2009; Sunarsi et al., 2019). This has an impact on not achieving sales targets.

PT. AUTO 2000 is one of the companies engaged in the sale of cars, besides that it is also engaged in the business of importing Toyota car parts and car maintenance. In an increasingly competitive competition, PT. AUTO 2000 tries to increase sales and service quality. 


\section{0| Jurnal Office: Jurnal Pemikiran Ilmiah dan Pendidikan Administrasi Perkantoran \\ Vol. 6, No. 1, January-June 2020, Page 9-16}

Indonesia is a very potential market for other countries to market their products (Astuti et al., 2015; Maharani \& Gozali, 2015; Murtiasih et al., 2013). There have been many car manufacturers from various countries who have entered the automotive market in Indonesia. The Indonesian Automobile Industry Association (AIMI) estimates that the motorcycle market will continue to increase in the coming years with increases ranging from 12.5 to 15 percent. PT Toyota International Tbk (AUTO 2000) is a pioneer of the car industry in Indonesia and until now this company has become a "Top of Mind" in Indonesian society.

For its promotional activities, AUTO 2000 carries the theme of family vehicles and strengthens the corporate brand image campaign by introducing added value to the company that is reflected in products and technology. Also, PT. AUTO 2000 Bintaro has a booking service program that makes it easy for consumers to care for consumer cars, express maintenance, which is in the form of service or vehicle maintenance that is done quickly, in just one hour and Toyota Home Service (THS) where this service makes it easy for busy customers to do light service at the customer's house with the same quality and price.

In supporting sales, the role of the budget is quite important because it is part of the sales strategy carried out by marketing.

The company as a work unit always tries to organize all available resources so that maximum results can be achieved in production activities, which in turn can increase sales results. One way to increase sales results can be done by doing promotions.

In modern marketing, companies not only develop quality products, fix prices, and place products that are affordable to consumers, but companies communicate with consumers to find out what consumers need and want. Communication that is usually carried out by companies is by promotion.

PT. Auto 2000 Bintaro is a special Toyota car dealer which is a marketing and sales network of PT. Toyota Astra, which has several types of Toyota car models, namely the Toyota Avanza, Toyota New Vios, Toyota Yaris, Toyota Camry, Toyota Innova, Toyota Agya, Toyota Rush, Toyota Corolla ALTIS, Toyota Fortuner, Alphard, Land Cruiser, and Toyota Crown Royal Saloon.

Sales promotion is a customer relationship, not just creating short-term sales results (Mussel, Aurier, \& de Lanauze, 2019; Sinha \& Verma, 2020)s. In terms of sales of PT. Auto 2000 Bintaro is aiming for the lower economy class market share for the minibus type, while the sedan for the economy class and above. Sales promotion needs to strengthen product position and build long-term relationships. In terms of the sales force owned by AUTO 2000 is not comparable with the target set by the company.

Marketing personnel (marketing) owned by PT. AUTO 2000 still has to keep improving its sales strategy, given the vast market and the car industry is getting more competitive, so the marketing personnel from the same industry (competitors) have decided to add a more reliable salesforce considering that the competition in vehicle sales is so tight. Mastery of a certain product class is part of a competitor's strategy by utilizing competent human resources. Thus, PT. AUTO 2000 should think about the right sales strategy including the addition of competent marketing personnel so that they can answer market challenges and realize sales targets set by the company. 
Based on the general description of the above problems, the researcher is interested in discussing the issue of promotional costs associated with sales by taking the research title "The Effect of Promotion on Purchasing Decisions at PT. AUTO 2000 Bintaro".

\section{METHOD}

The type of research used is associative, where the aim is to find out how to find the relationship between the independent variable and the dependent variable. The population in this study amounted to 85 respondents PT. AUTO 2000 Bintaro. The sampling technique in this study was a saturated sample, where all members of the population were sampled. Thus the sample in this study amounted to 85 respondents. In analyzing the data used validity test, reliability test, simple linear regression analysis, correlation coefficient, determination coefficient, and hypothesis testing.

\section{RESULT AND DISCUSSION}

\section{Promotion}

In this test, it is used to determine the highest minimum and maximum score, the rating score, and the standard deviation of each variable. The results are as follows:

Table 1.

Results of Descriptive Statistics Analysis

Descriptive Statistics

\begin{tabular}{lr|r|r|r|r}
\hline & N & \multicolumn{1}{c}{ Minimum } & Maximum & Mean & \multicolumn{1}{c}{ Std. Deviation } \\
\hline Promotion (X1) & 96 & 28 & 44 & 34.11 & 3.612 \\
\hline Valid N (listwise) & 96 & & & & \\
\hline
\end{tabular}

Promotion obtained a minimum variance of 28 and a maximum variance of 44 with a rating score of 3.42 with a standard deviation of 3.612 .

\section{Buying Decision}

In this test, it is used to determine the highest minimum and maximum score, the rating score, and the standard deviation of each variable. The results are as follows:

Table 2.

Results of Descriptive Statistics Analysis

Descriptive Statistics

\begin{tabular}{lr|r|r|r|r}
\hline & N & \multicolumn{1}{c}{ Minimum } & \multicolumn{1}{c}{ Maximum } & Mean & Std. Deviation \\
\hline Buying decision (Y) & 96 & 31 & 49 & 38.36 & 4.037 \\
\hline Valid N (listwise) & 96 & & & & \\
\hline
\end{tabular}


12 Jurnal Office: Jurnal Pemikiran Ilmiah dan Pendidikan Administrasi Perkantoran

Vol. 6, No. 1, January-June 2020, Page 9-16

The purchase decision obtained a minimum variance of 31 and a maximum variance of 49 with a rating score of 3.83 with a standard deviation of 4.037 .

\section{Effect of Promotion on Purchasing Decisions}

This analysis aims to determine the effect of the independent variable on the dependent variable.

This regression test is intended to determine changes in the dependent variable if the independent variable changes. The test results are as follows:

Table 3.

Simple Linear Regression Test Results

\begin{tabular}{|c|c|c|c|c|c|}
\hline \multirow[b]{3}{*}{ Model } & \multicolumn{2}{|c|}{ Coefficients $^{\mathrm{a}}$} & \multirow{3}{*}{$\begin{array}{l}\text { Standardized } \\
\text { Coefficients }\end{array}$} & \multirow[b]{3}{*}{$t$} & \multirow[b]{3}{*}{ Sig. } \\
\hline & $\begin{array}{r}\text { Unst } \\
\text { Co }\end{array}$ & $\begin{array}{l}\text { dardized } \\
\text { ficients }\end{array}$ & & & \\
\hline & B & Std. Error & & & \\
\hline 1 (Constant) & 8.949 & 2.515 & & 3.558 & .001 \\
\hline Job Promotion (X) & .862 & .073 & .772 & 11.760 & .000 \\
\hline
\end{tabular}

a. Dependent Variable: Buying decision (Y)

Based on the test results in the table above, the regression equation $\mathrm{Y}=8.949+0.862 \mathrm{X}$ is obtained. From the equation, it is explained that a constant of 8.949 means that if there is no promotion and motivation, then there is a purchase decision value of 8.949 points; Promotion regression coefficient of 0.862 , this figure is positive, meaning that every time there is an increase in Promotion of 0.862 , the Purchase Decision will also increase by 0.862 points.

Correlation coefficient analysis is intended to determine the level of the strength of the relationship between the independent variable and the dependent variable either partially or simultaneously. The test results are as follows:

Table 4.

Results of Testing the Promotion Correlation Coefficient of Purchasing Decisions Correlations $^{\mathrm{b}}$

\begin{tabular}{llr|r}
\hline & & Promotion $(\mathrm{X} 1)$ & Buying decision (Y) \\
\hline Promotion (X) & Pearson Correlation & 1 & $.772^{* *}$ \\
\cline { 2 - 4 } & Sig. (2-tailed) & & .000 \\
\hline Buying decision (Y) & Pearson Correlation & $.772^{* *}$ & 1 \\
\cline { 2 - 4 } & Sig. (2-tailed) & .000 & \\
\hline
\end{tabular}

**. Correlation is significant at the 0.01 level (2-tailed).

b. Listwise $\mathrm{N}=96$ 
Based on the test results obtained a correlation value of 0.772 means that Promotion has a strong relationship with Purchasing Decisions.

Analysis of the coefficient of determination is intended to determine the percentage of influence of the independent variable on the dependent variable. The test results are as follows:

Table 5.

Results of Testing the Promotion Determination Coefficient on Purchasing Decisions Model Summary

\begin{tabular}{lrr|rr|r}
\hline Model & & \multicolumn{2}{c|}{$\begin{array}{c}\text { Adjusted R } \\
\text { Square }\end{array}$} & \multicolumn{2}{c}{$\begin{array}{c}\text { Std. Error of the } \\
\text { Estimate }\end{array}$} \\
\hline 1 & $\mathrm{R}$ & R Square & .595 & .591 & 2.582 \\
\hline
\end{tabular}

a. Predictors: (Constant), Promotion (X1)

Based on the test results obtained a determination value of 0.595 means that Promotion has an influence contribution of $59.5 \%$ on the Purchase Decision.

Hypothesis testing with the t-test is used to determine which hypothesis is accepted. Hypothesis formulation: there is a significant influence between Promotion on Purchasing Decisions.

Table 6.

Promotion Hypothesis Test Results Against Purchasing Decisions

Coefficients $^{\mathbf{a}}$

Unstandardized

Coefficients

\begin{tabular}{ll|l} 
Model & B & Std. Error \\
\hline 1
\end{tabular}

Standardized

Coefficients

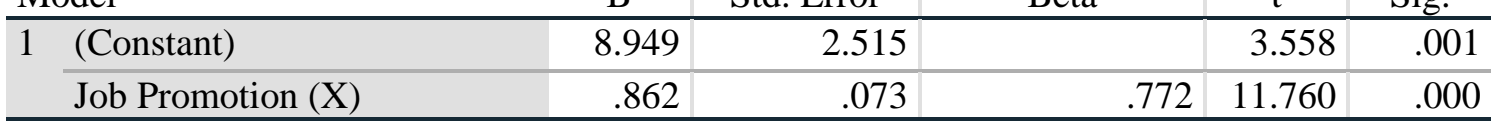

a. Dependent Variable: Buying decision (Y)

Based on the test results in the table above, the value of $t$ count $>t$ table or $(11,760>1,986)$ is obtained, thus the hypothesis that there is a significant effect between Promotion on Purchasing Decisions is accepted.

\section{Discussion}

\section{Promotion}

Based on the respondents' answers, the promotion variable obtained a rating score of 3.42 in the scale range from 3.40 to 4.19 with good or agree on criteria.

\section{Buying decision}

Based on the respondent's answer, the Purchasing Decision variable obtained a rating score of 3.83 in the scale range from 3.40 to 4.19 with good or agree on criteria. 
14| Jurnal Office: Jurnal Pemikiran Ilmiah dan Pendidikan Administrasi Perkantoran

Vol. 6, No. 1, January-June 2020, Page 9-16

\section{Effect of Promotion on Purchasing Decisions}

The promotion has a significant effect on purchasing decisions with the regression equation $\mathrm{Y}=17.517+0.565 \mathrm{X}$, the correlation value is 0.772 or has a strong relationship with the contribution of the influence of 59.5\%. Hypothesis testing obtained t value $>t$ table or (11.760> 1.986). Thus the hypothesis proposed that there is a significant effect between Promotion on Purchasing Decisions is accepted.

\section{CONCLUSION}

Based on the results and discussion of this study, it can be concluded that the promotion variable obtained a rating score of 3.42 in the scale range of $3.40-4.19$ with good or agree on criteria; the Purchasing Decision variable obtained a rating score of 3.83 in the scale range from 3.40 to 4.19 with good or agree on criteria; Promotion has a significant effect on purchasing decisions with the regression equation $\mathrm{Y}=17.517+0.565 \mathrm{X}$, the correlation value is 0.772 or strong and the influence contribution is $59.5 \%$, while the remaining $57.9 \%$ is influenced by other factors. Hypothesis test obtained t value> $t$ table or (11.760> 1.986).

\section{REFERENCES}

Abishovna, B. A. (2014). The Principle of Effective Marketing Management. Procedia - Social and Behavioral Sciences, 109, 1322-1325. https://doi.org/https://doi.org/10.1016/j.sbspro.2013.12.632

Adams, P., Bodas Freitas, I. M., \& Fontana, R. (2019). Strategic orientation, innovation performance and the moderating influence of marketing management. Journal of Business Research, 97, 129-140. https://doi.org/https://doi.org/10.1016/j.jbusres.2018.12.071

Astuti, R., Silalahi, R. L. R., \& Wijaya, G. D. P. (2015). Marketing Strategy Based on Marketing Mix Influence on Purchasing Decisions of Malang Apples Consumers at Giant Olympic Garden Mall (MOG), Malang City, East Java Province, Indonesia. Agriculture and Agricultural Science Procedia, 3, 67-71. https://doi.org/https://doi.org/10.1016/j.aaspro.2015.01.015

Chiu, C.-H., Choi, T.-M., \& Li, X. (2011). Supply chain coordination with risk sensitive retailer under target sales rebate. Automatica, 47(8), 1617-1625. https://doi.org/https://doi.org/10.1016/j.automatica.2011.04.012

Cusumano, M. A., \& Nobeoka, K. (1992). Strategy, structure and performance in product development: Observations from the auto industry. Research Policy, 21(3), 265-293. https://doi.org/https://doi.org/10.1016/0048-7333(92)90020-5

Ellram, L. M., \& Ueltschy Murfield, M. L. (2019). Supply chain management in industrial marketing-Relationships matter. Industrial Marketing Management, 79, 36-45. 
https://doi.org/https://doi.org/10.1016/j.indmarman.2019.03.007

Harriss, J. (1995). "Japanization": Context and culture in the Indonesian automotive industry. World Development, 23(1), 117-128. https://doi.org/https://doi.org/10.1016/0305750X(94)00109-C

Maharani, W., \& Gozali, A. A. (2015). Collaborative Social Network Analysis and Contentbased Approach to Improve the Marketing Strategy of SMEs in Indonesia. Procedia Computer Science, 59, 373-381. https://doi.org/https://doi.org/10.1016/j.procs.2015.07.540

Murtiasih, S., Sucherly, \& Siringoringo, H. (2013). How Word of Mouth Influence Brand Equity for Automotive Products in Indonesia. Procedia - Social and Behavioral Sciences, 81, 40-44. https://doi.org/https://doi.org/10.1016/j.sbspro.2013.06.384

Mussol, S., Aurier, P., \& de Lanauze, G. S. (2019). Developing in-store brand strategies and relational expression through sales promotions. Journal of Retailing and Consumer Services, 47, 241-250. https://doi.org/https://doi.org/10.1016/j.jretconser.2018.11.020

Nurcahyo, R., \& Wibowo, A. D. (2015). Manufacturing Capability, Manufacturing Strategy and Performance of Indonesia Automotive Component Manufacturer. Procedia CIRP, 26, 653-657. https://doi.org/https://doi.org/10.1016/j.procir.2014.07.046

Passey, R., \& MacGill, I. (2009). Energy sales targets: An alternative to White Certificate schemes. Energy Policy, 37(6), 2310-2317. https://doi.org/https://doi.org/10.1016/j.enpol.2009.02.029

Proff, H. (2000). Hybrid strategies as a strategic challenge - the case of the German automotive industry. Omega, 28(5), 541-553. https://doi.org/https://doi.org/10.1016/S0305-0483(00)00018-9

Shander, O., Shumyk, D., Shander, Y., \& Ischuka, O. (2019). Improving the technology of freight car fleet management of operator company. Procedia Computer Science, 149, 5056. https://doi.org/https://doi.org/10.1016/j.procs.2019.01.106

Sinha, S. K., \& Verma, P. (2020). Impact of sales Promotion's benefits on perceived value: Does product category moderate the results? Journal of Retailing and Consumer Services, 52, 101887. https://doi.org/https://doi.org/10.1016/j.jretconser.2019.101887

Sunarsi, D., Kustini, E., Lutfi, A. M., Fauzi, R. D., \& Noryani, N. (2019). Penyuluhan Wirausaha Home Industry Untuk Meningkatkan Ekonomi Keluarga Dengan Daur Ulang Barang Bekas. BAKTIMAS: Jurnal Pengabdian Pada Masyarakat, 1(4), 188-193. 
16| Jurnal Office: Jurnal Pemikiran Ilmiah dan Pendidikan Administrasi Perkantoran Vol. 6, No. 1, January-June 2020, Page 9-16 